\section{ARCHAOLOGICAL RESEARCHES IN GUATEMALA.}

THE Peabody Museum of American Archæology and Ethnology of Harvard has already rendered signal service by publishing the results of Mr. Teobert Maler's journeys and researches among the ruins of ancient Indian towns and cities on the banks of the River Usumatsintla and the adjacent region. We are now favoured with the first instalment of the account of Mr. Maler's last expedition, describing the ruins of Yaxhá, Naranjo, \&c. Although the expedition commenced with the explorations of the ruins of Tikal, the records of the second part of this expedition are given first, and the account of the exploration of Tikal is to be published later. However, there is no lack of interest in this first instalment, and $\mathrm{Mr}$. Maler's photographs of the sculptured monuments are as excellent as those he made of Seibal, Piedras Negras, Yaxchilan (Menché), which is saying that they are as good as it is possible to make them.

Before passing on to the account of his discoveries, we must congratulate Mr. Maler (who commenced his connection with tropical America as an officer in the service of the Emperor Maximilian) on his pluck and endurance in undertaking and carrying to a successful issuc such an arduous enterprise in the years 1904-5. He is, indeed, the well-tried veteran of Central American archæological exploration. $\mathrm{Mr}$. Maler passes lightly over his hardships and discomforts, yet it needs but little personal experience to appreciate how great the discomfort can be in travelling through the low-lying and frequently flooded forests of northern Guatemala; but Mr. Maler's enthusiasm for his work and knowledge of the natives would carry him over obstacles which would daunt and discourage many a younger man. Food in that country is always scarce, and workmen to accompany the traveller are most difficult to obtain.

After completing his investigations at Tikál in November, I904, Mr. Maler returned to the east end of Lake Petén and struck through the forest to the east for a distance of about fourteen leagues, following, when possible, the paths of the "chicle", gatherers, until he reached the shores of the Lake of Yaxha. Chicle is the gum which exudes when an incision is made in bark of the Chico Sapote tree, and is used as the basis of American chewinggum. It is curious to note the complete demoralisation that chicle-hunting has entailed on the very scanty population of Petén. "No one will plant a milpa (a maize field), and even the poorest ragamuffin proudly refuses to do any work, saying ' I am a Chiclero and have no need to work for anyone.' The result is that a general famine occurs nearly every year in Petén, which would otherwise yield an over-lavish abundance. Hence all the Chicleros are poverty-stricken, and, being heavily in debt, from which they never free themselves, they no longer have huts or milpas and no regular wife or children; for this unsettled life in the forests, interrupted occasionally by debauches in this or that village, puts even the most unpretentious form of family life out of the question."

On an island named Topoxté, in the lake of Yaxhá, Mr. Maler discovered the remains of one temple of considerable size and several other buildings, and secured photographs of the fragments of some sculptured stelæ. Then directing his attention to the north shore of the lake, he explored a long line of ruined temples and other buildings extending for a

1 Memoirs of the Peabody Museum of American Archæology and Ethnology, Harvard University. Vol. iv., No. 2. Explorations in the Department of Petén, Guatemala and Adjacent Region. By T. Maler. Pp. 55-127 + (14-44) plates. (Cambridge, Mass. : Published by the Museum, 19o8.)

NO. 2058, VOL. 8o] distance of more than three kilometres, and found the broken remains of ten sculptured stelæ.

Mr. Maler makes a note of the fact that the waters of Lake Yaxhá have risen at least one metre during the last twenty-five years, and that the level of the water in the lake of Petén Itzá also shows a considerable rise during that period.

In January, 1905, Mr. Maler left Yaxhá for Benque Viejo, within the boundary of British Honduras, and in February returned through the forest to the ruin known as Naranjo, previously unexplored. This was indeed a considerable discovery, as the ruins are very extensive, and $\mathrm{Mr}$.

Maler was fortunate in discovering forty - three stelæ, many of them in good preservation and adorned with sculptured figures and hieroglyphic inscriptions. Unfortunately, the buildings are far advanced in ruin, and none of the rooms could be made available for habitation, and so Mr. Maler had to seek shelter during the three months of this stay in a small cave, and here, during the night time, he developed the splendid series of photographs which accompany his report.

Two of these photographs are h e r e reproduced, one to show the excellence of the sculpture (Fig. I), and the other (Fig. 2) to show the importance of the inscriptions and to emphasise the disappointment which must always be attached to the exa $m$ in ation of carved inscriptions

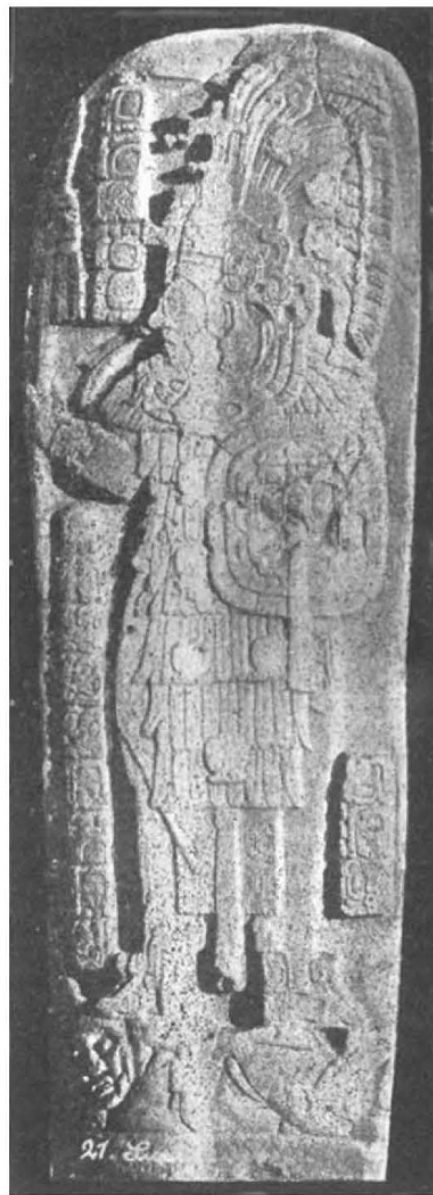

Fitg. 1.-Naranjo: Stela 21, South Side. when photography alone is relied on for recording them. The inscription is weather-worn, but it is sure to be as perfect a photograph as could be obtained in the surrounding conditions, yet it would not be possible to analyse the inscription from this record alone. Paper moulds or squeezes are so perfectly suitable for recording sculpture of this character, and the Peabody Museum has already secured such a fine collection of casts of inscriptions by this method, that it is to be hoped they will do justice to Mr. Maler's discoveries by sending an expedition to make paper moulds of all the sculptures and inscriptions for careful study by the well-qualified staff of the museum.

In digging round the fallen stelæ, several of the curiously shaped flint objects were unearthed like 
those discovered by Dr. Gann in a similar position in the ruin near Benque Viejo (Proc. of the Society of Antiquaries, May, I895), and this fully establishes the connection of these curious objects with the builders of these now ruined cities.

On returning to British Honduras, at the frontier village of El Cayo Mr. Maler met Mr. Blancanaux, a well-known collector of natural-history specimens, who told him that in the year $\mathbf{1 8 8 2}$ he had included among specimens forwarded from the Island of Cozumel to the British Museum, two ancient maps of Yucatan, drawn on bark or agave paper. Careful inquiries have been made at the British Museum, both at Bloomsbury and South Kensington, but no

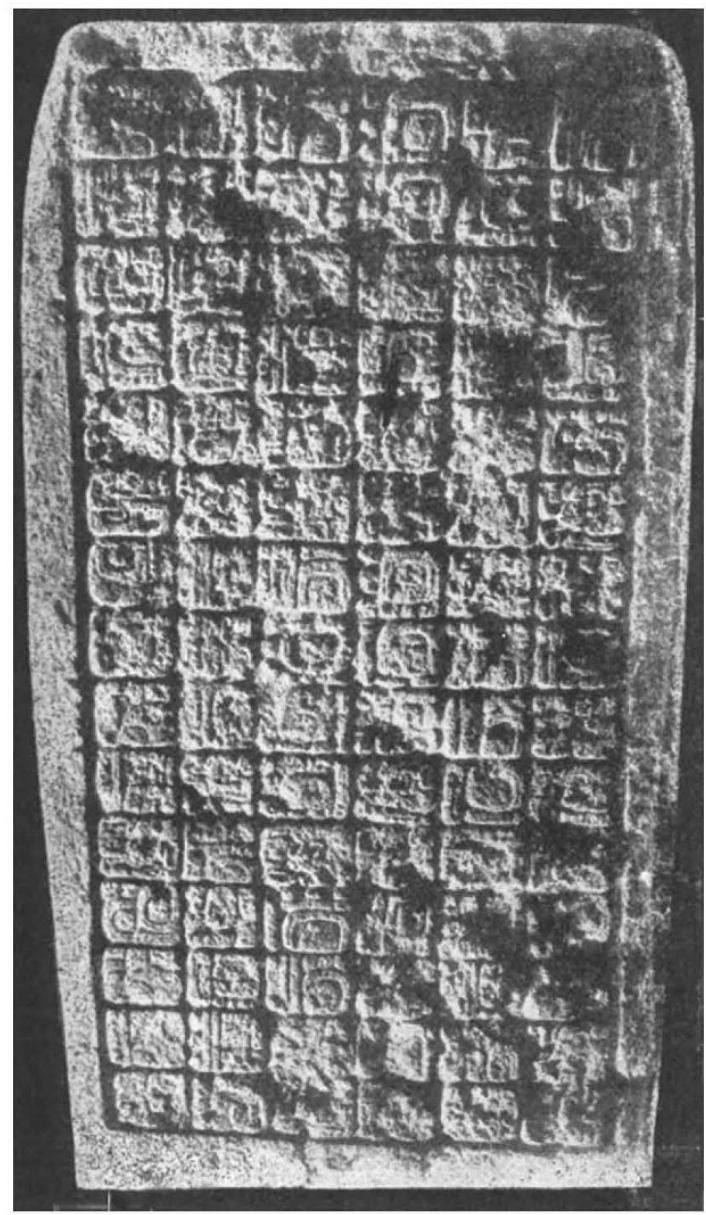

FIG. 2.-Naranjo: Stela 30, East Side.

trace of their arrival can be found. There is very little probability of their having been overlooked, as is suggested, because they were packed among natural-history specimens, for ethnological and other objects are frequently sent with such specimens, and when unpacked are at once handed over to the department concerned with them, and that such a valuable prize as two manuscript maps on some form of native paper could be overlooked is hardly possible. However, Mr. Blancaneaux is being communicated with, and every effort will be made to clear the matter up.

The next instalment of Mr. Maler's work describing his explorations of Tikál, one of the most interesting ruins in Central America, will be looked for with the greatest interest.

\section{ZOOLOGY OF THE ANTARCTIC. ${ }^{1}$}

FROM first to last there was high courage in the Scotia voyage. Dr. Bruce organised it singlehanded, backed, of course, by generous pecuniary help from Mr. Coats and others, and he brought it to a successful finish with a minimun of loss or wastage. We do not forget the wise and wary captain and his loyal crew, or the fearless company of scientific assistants, or those who have helped to work up the results; but as volume follows volume from the unpretentious, hardworking laboratory at Surgeons' Hall in Edinburgh, we cannot withhold our admiration for what has been accomplished essentially by Dr. Bruce's pluck and determination. Both these qualities will be needed, we fear, before the tale of the Scotia voyage is fully told, for working up and editing scientific results is an arduous and uniemunerative business, requiring all the encouragement it can get and a great deal more. "More power to your elbow, sir, in this unromantic age."

The two volumes before us are very different. The first is an entertaining zoological log, as logs go, that is, illustrated with a hundred beautiful and interesting photographs, and introduced by a charming picture by an artist who has himself seen ice. The second is a collection of technical reports by a dozen different workers, and though it is quite as interesting as the $\log$, it appeals to a smaller circle. The log would have stood some more proof-reading, but we are glad to say that no attempt has been made to touch it up. It is a field note-book of the natural history of the voyage and of the wintering in Scotia Bay, South Orkneys, and it is full of interesting facts. We do not depreciate its interest when we say that with its splendid series of illustrations it would make an admirable book for any boy-naturalist who likes to get into close grips with the real thing. We wish to direct attention to the very fine set of photographs of penguins, shags, skuas, petrels, seals, and sea-lions, taken on the spot, and to the exceptionally good photographs of starfish, isopods, alcyonarians, and so forth taken in the laboratory by Mr. T. C. Dey. As a sample of the $\log$ we quote from October Ir, I903:-“"The adelia penguins were nearly all actively collecting stones or resting from their labours, sleeping near their little heaps, either upright or prone. Some were very active and moved over ten yards at times in search of a good stone to return with; they throw the stones down in no apparent order. Thieving was being carried on extensively. The intending thief moved towards a heap the owner of which was away or not looking, and if he saw his chance picked up a stone and returned with it; but if the owner turned and spotted the thief approaching, the intending culprit walked innocently by as if nothing was further from his intentions than stealing a stone. If a thief was caught, the owner bit at him viciously and thus warned him off for the occasion, but as soon as an opportunity again presented itself he returned once more on thieving bent. I noticed several adelias eating snow in large quantities."

The various reports in the more technical volume have been mostly passed through the Transactions of the Royal Society of Edinburgh, which has thus aided in the publication. They are interesting in many different ways. Sometimes it is an isolated fact of

1 Report on the Scientific Results of the Voyage of S.Y. Scotia during the Years 1902,1903 , and 1904 , under the Leadership of Dr. William S. the Years 1902,1903 , and 1904 , under the Leadersh, by David W. Wilton, Dr. J. H. Harvie Pirie, and R. N. Rudmose Brown. Thirty-three plates and 2. maps, including roo photographs by the Editor and the Authors; coloured 2. maps, including roo photographs by the Editor antispiece by William Smith. Pp. xiv +104. (Edinburgh: The Scottish Oceanographical Laboratory; Edinburgh: Thin; Glasgow : Maclehose, 1908.) Price 13s. net, cloth, or ros. $6 d$. paper. Vol. v., Zoology. Parts i.-xiii., Invertebrates. Pp $x i+313 ; 36$ plates. Price $23^{s}$. $6 d$. cloth, 2 ts. paper. 